\title{
Validity of Mathematics Learning Devices Based on Quantum Teaching to Improve The Problem Solving Ability of Students Class XI Vocational School
}

\author{
$1^{\text {st }}$ Riza Silfia \\ Department of Mathematics \\ Padang State University \\ Padang, Indonesia \\ riizasilfia@gmail.com
}

\author{
$2^{\text {nd }}$ Irwan \\ Department of Mathematics \\ Padang State University \\ Padang, Indonesia \\ irwan@fmipa.unp.ac.id
}

\begin{abstract}
This study aims to produce a valid mathematics learning devices for class XI vocational school. The devices developed are learning plan and student's worksheets based on quantum teaching. The development model used in this research is a Plomp model consisting of 3 phases, that is preliminary research, prototyping stage, and assessment stage. But the thing that is focused in this research is prototype development stage that is in stage of validity by expert. Aspects assessed at the validation stage are aspects of language, aspects of presentation /didactic, content aspects, and aspects of graffiti. The end result of this research is to produce a valid mathematics learning device based on quantum teaching.
\end{abstract}

Keywords-Validation, Learning Devices, Quantum Teaching

\section{INTRODUCTION}

Mathematics is a subject that has important roles and functions for students in every level of education ranging from elementary school (SD) even up to university. There are many reasons why mathematics has an important role or function for students. As stated by Cornelius that there are five reasons for the need to learn mathematics because mathematics is (1) a clear and logical means of thinking, (2) the means to solve problems of everyday life, (3) Patterns of relationship and generalization of experience, (4) means to develop creativity, and (5) means to raise awareness of cultural development [1].

Furthermore Cockroft, argues that mathematics needs to be taught to students because (1) Mathematics is regarded by most people as being essential, (2) Mathematics is only one of many subjects which are included in the school curriculum, (3) Mathematics provides a means of communication which is powerful, concise and unambiguous, (4) Mathematics can be used to present information in many ways, (5) Develop powers of logical thinking, accuracy, and spatial awareness, and (6) Give satisfaction to attempt to solve challenging problems) [2].

From some of the above opinion we can know that one of the learning functions of Mathematics is as a means to train the problem solving skills of learners. To perform the mathematical functions as a means to train the problem solving skills of learners then the ability to solve mathematical problems must also be one of the goals of learning mathematics itself. As stated in Permendikbud RI No.58 year 2014 at point 2 is one of the objectives of learning mathematics is that learners can use the pattern as a conjecture in problem solving and able to make generalizations based on phenomena or existing data. This means that the ability to solve mathematical problems is a goal of mathematical learning according to Permendikbud (government regulations). Although problem-solving skills are very important in mathematics learning activities, the reality of students' problem-solving ability is still low.

The low ability of problem solving mathematical learners also seen the results of observations that have been done in several vocational school in Agam Regency. Observation is done by giving a problem-solving test. The test was given to the students of SMK N 1 Lubuk Basung in class XI Akuntansi 2 followed by 29 students, SMK N 2 Lubuk Basung in class XI TKJ 1 followed by 29 students, and SMK Plus Perbankan in class XI Akuntansi 1 followed by 29 students. Table 1 below shows the results of mathematical problem solving test of learners in SMK N 1 Lubuk Basung, SMK N 2 Lubuk Basung, and SMK Plus Perbankan.

TABLE 1. OBSERVATION RESULTS OF MATHEMATICAL PROBLEM SOLVING TEST

\begin{tabular}{|c|c|c|c|}
\hline & $\begin{array}{c}\text { SMK N 1 } \\
\text { Lubuk Basung }\end{array}$ & $\begin{array}{c}\text { SMK N 2 } \\
\text { Lubuk Basung }\end{array}$ & $\begin{array}{c}\text { SMK Plus } \\
\text { Perbankan }\end{array}$ \\
\hline $\begin{array}{c}\text { Understand the } \\
\text { problem }\end{array}$ & $28 \%$ & $24 \%$ & $34 \%$ \\
\hline To make a plant & $24 \%$ & $17 \%$ & $31 \%$ \\
\hline $\begin{array}{c}\text { Carry out our } \\
\text { plan }\end{array}$ & $14 \%$ & $14 \%$ & $24 \%$ \\
\hline $\begin{array}{c}\text { We look back at } \\
\text { the completed } \\
\text { solution }\end{array}$ & $7 \%$ & $4 \%$ & $7 \%$ \\
\hline
\end{tabular}

From table 1 we can know that the early ability to solve mathematical problems of students both in SMK N 1 Lubuk Basung, SMK N 2 Lubuk Basung and SMK Plus Perbankan are still relatively low.

From the observations that have been done by the researchers, the low ability of problem solving learners caused by several factors, including: (1) the lack of learning resources used in the learning process, (2) Student's worksheets used so far does not contain adequate activities for learners to construct his understanding to find a 
mathematical concept, (3) the problems that exist in student's worksheets used so far do not contain the contextual or story problem so that learners are not accustomed to solving the story problem, while for the present era learners are expected to be able to do the HOTS one of the criteria of the problem is contextual, and (4) the activities in the Learning plan do not show the activities that lead the learners to be active and can find the mathematical concepts learned

From the above problem it can be concluded that learning plan and student's worksheets used so far not optimal. Where learning plan and student's worksheets used so far has not been supporting the learning activities of learners to be able to improve problem-solving skills. It is very unfortunate that the learning plan and student's worksheets used in schools so far has not been fully able to meet the needs of learners. Learning plan is a tool that can assist teachers in managing the stages to be done in the classroom and student's worksheets can facilitate teachers and learners in implementing learning in the classroom. with student's worksheets can improve the problem solving ability of learners, because in student's worksheets loaded questions that will guide learners to train problem-solving skills. so, learning plan and student's worksheets are two things that help teachers and learners in learning.

Along with the need for learning plan and student's worksheets that can support the problem solving ability of learners, it is necessary also a learning approach that can be used as a foundation in developing learning plan and student's worksheets. Learning plan and student's worksheets developed will be more optimal in improving the problem solving ability of learners, if learning plan and student's worksheets is based on one learning approach that also has a goal to improve the problem solving ability of learners and teaches students how to solve a problem. One of model used to achieve that goal is quantum teaching model.

Quantum Teaching is a learning model that provides new ways to facilitate the learning process through the integration of elements of art and targeted achievements that are used by the teacher as a guide in planning and implementing learning in the classroom. The quantum teaching Design Framework is known as the TANDUR design term (DePorter 2009; 88) $[4,5]$.

Quantum Teaching is a model that is considered capable of improving the problem solving skills of learners, because in solving a problem will certainly involve a high-level thinking process [3].

In this process of thinking, an idea cannot suddenly come to mind. Ideas occur after various symbols are processed so that it can be said that in the process of thinking it will pass through several mental reconstruction stages as follows: (1) Grow the interest of students, before the lesson begins the teacher conveys the learning objectives and competencies expected to be achieved. Then the teacher recounts the benefits of learning the material to be studied and connecting the material with everyday problems (the real world). After they know the benefits it will arise students' interest to study the material seriously, (2) Natural, namely to provide learning experiences to students, (3) Name, Learners are guided to find definitions, keywords, models and formulas regarding questions on L student's worksheets. Students together with their group friends discuss and try to answer the problems that exist in student's worksheets, (4) Demonstrate, at this stage the teacher gives students time and opportunity to display the results of the discussion in front of the class, (5) Repeat, at this stage the teacher gives time to learners to make notes about the material they just learned, and (6) Celebrate, provide reinforcement to students so that all students feel valued. This means that the celebration will be able to strengthen the next learning process. The learning that has the above characteristics is a quantum teaching learning model.

Based on the problems that have been described above, the researcher develops a quantum teaching based learning device. The development model used in this research is the Plomp model which has three stages, namely the introduction stage, the development stage or the prototype making, and the assessment stage. The purpose of this development is to acquire learning tools that are valid, practical, and effective. This means that learning devices that will be used in schools must be valid, practical, and effective first. But in this study focused on the validity of learning devices developed. So the research question in this research is "How is validity of mathematics learning devices based on a quantum teaching to improve the problem solving ability of students class XI vocational school?

\section{METHODS}

This research is a research development with development of Plomp model. The author uses this model because it is more systematic, directed, analytical, and suitable for developing learning tools. The Plomp model consists of three phases, namely the preliminary research phase, the prototype development or prototyping phase, and the assessment phase [5]. The validation stage is at the stage of development or manufacture of prototypes. Validation is done by 5 experts consisting of 3 experts mathematics, 1 expert Indonesian language, and 1 person from education technology experts. Mathematicians will review the device from content and didactic aspects, language experts will review from the language aspect, and educational technology experts will review from the aspect of graffiti. The instruments used to collect data are the learning plan and student's worksheets validation sheets that have been validated by 2 mathematicians and 1 language expert. In this study, the average score ( $r$ ) of expert assessment results is adjusted according to the criteria of device assessment based on the criteria of device validity according to Muliyardi which can be seen in table 2 [6]

TABLE 2. CRITERIA OF LEARNING DEVICED VALIDITY

\begin{tabular}{|l|c|}
\hline \multicolumn{1}{|c|}{ Interpretation } & Criteria \\
\hline $\mathrm{R} \leq 0,08$ & Invalid \\
\hline $0,08<\mathrm{R} \leq 1,60$ & Less valid \\
\hline $1,60<\mathrm{R} \leq 2,40$ & Quite valid \\
\hline $2,40<\mathrm{R} \leq 3,20$ & Valid \\
\hline $\mathrm{R}>3,20$ & Very valid \\
\hline
\end{tabular}

The device is said to be valid if it has a scoring average score of experts / validator $>2.40$. 


\section{RESULT AND DISCUSSION}

learning devices developed in the research are learning plan and student's worksheets . learning device development process refers to the plomp model. next will be explained and discussed briefly the results of learning plan and student's worksheets validation based on Quantum Teaching.

\section{Learning Plan}

The learning implementation plan developed in this research is based on the Quantum Teaching, in which the core activities of better learning are on the steps of the Quantum Teaching (TANDUR). Learning plan designed for math materials class XI SMK semester 1 . In the validation phase, learning learning plan implemented by 4 experts consisting of 3 mathematicians and 1 person from the indonesian language. Aspects of learning plan are validated by the expert is linguistic, didactic / presentation, and content aspects. The validation result of Quantum Teaching based learning plan by 4 people can be seen based on table 3 below.

TABLE 3. RESULTS OF THE VALIDATION OF THE IMPLEMENTATION PLAN OF LEARNING BY EXPERTS

\begin{tabular}{|c|c|c|c|c|c|c|}
\hline \multirow{2}{*}{$\begin{array}{c}\text { Rated } \\
\text { Aspect }\end{array}$} & \multicolumn{4}{|c|}{ Average score from validator } & \multirow{2}{*}{$\begin{array}{l}\text { Avera } \\
\text { ge }\end{array}$} & \multirow{2}{*}{ Criteria } \\
\hline & $V 1$ & $V 2$ & V3 & V4 & & \\
\hline Linguistic & 3 & 4 & 3 & 4 & 3,5 & $\begin{array}{l}\text { Very } \\
\text { Valid }\end{array}$ \\
\hline Didactic & 3,25 & 4,00 & 3,50 & 3,88 & 3,66 & $\begin{array}{l}\text { Very } \\
\text { Valid } \\
\end{array}$ \\
\hline Content & 3,03 & 4,00 & 3,34 & 3,94 & 3,58 & $\begin{array}{l}\text { Very } \\
\text { Valid } \\
\end{array}$ \\
\hline Average & 3,09 & 4,00 & 3,37 & 3,93 & 3,60 & $\begin{array}{l}\text { Very } \\
\text { Valid }\end{array}$ \\
\hline
\end{tabular}

Adjective

V1 is validator 1 (Dr. Yerizon, M.Si)

V2 is validator 2 (Dr. Dony Permana, M.Si)

V3 is validator 3 (Drs. Hendra Syarifuddin, M.Si, Ph.D)

V4 is validator 4 (Dr. Abdurrahman, M.Pd)

From table 3 we can see that the learning implementation plan (learning plan) that has been designed by the researcher is valid for every aspect of the assessment (language, dictication, and content). This is because the compilation of learning plan in accordance with the provision of learning plan according to permendikbud number 81a year 2013. In addition, the learning plan is compiled is valid because the aspects of presentation, language, and content have been in accordance or meet the criteria of good [7]. However, linguistic aspects get the lowest average compared to other aspects, this is because there are still many mistakes in typing and punctuation, then this needs to be corrected by the author.

In terms of the average rating each aspect is on very valid criteria. Nevertheless, there are still some things that need to be improved from the learning plan that has been designed by researchers. The following table 4 shows some of the things that need to be revised on the learning plan based on the suggestion of the validator.
TABLE 4. REVISED VALIDATION RESULTS OF LEARNING PLAN

\begin{tabular}{|c|c|}
\hline Before revision & After revision \\
\hline Lesson objectives are incomplete, & Complete learning objectives \\
\hline $\begin{array}{l}\text { Learning resources are less clear } \\
\text { (word "etc" remove, mention all } \\
\text { learning resources in detail) }\end{array}$ & $\begin{array}{l}\text { All learning resources are written } \\
\text { clearly }\end{array}$ \\
\hline $\begin{array}{l}\text { Motivation on preliminary activities } \\
\text { is not real }\end{array}$ & $\begin{array}{l}\text { Motivation on preliminary } \\
\text { activities is changed into } \\
\text { something real or real for } \\
\text { learners, for example with things } \\
\text { that are close to the learner }\end{array}$ \\
\hline $\begin{array}{l}\text { At the introduction stage there is no } \\
\text { teacher explanation of the lesson } \\
\text { steps to be taken }\end{array}$ & $\begin{array}{l}\text { Add a teacher's explanation of } \\
\text { the steps of the learning activities } \\
\text { at the introduction stage }\end{array}$ \\
\hline $\begin{array}{l}\text { down what student's } \\
\text { tement is used }\end{array}$ & $\begin{array}{l}\text { write down information for each } \\
\text { student's worksheets used for } \\
\text { each meeting }\end{array}$ \\
\hline $\begin{array}{l}\text { Attitudes observed in learning } \\
\text { activities are too numerous }\end{array}$ & $\begin{array}{l}\text { Minimize attitudes to be assessed } \\
\text { in the learning process, attitudes } \\
\text { assessed only that deemed } \\
\text { necessary and can be assessed } \\
\text { during learning alone }\end{array}$ \\
\hline $\begin{array}{l}\text { Not to mention the number of } \\
\text { questions that the learner will do as } \\
\text { an exercise in closing activities }\end{array}$ & $\begin{array}{l}\text { Mention the number of questions } \\
\text { a learner should do as an exercise } \\
\text { in closing activities }\end{array}$ \\
\hline $\begin{array}{l}\text { There are no learning in the } \\
\text { learning plan }\end{array}$ & $\begin{array}{l}\text { There are learning in the learning } \\
\text { plan }\end{array}$ \\
\hline $\begin{array}{l}\text { Not all the problems presented in } \\
\text { student's worksheets are written in } \\
\text { the learning plan }\end{array}$ & $\begin{array}{l}\text { Any problems given in the } \\
\text { learning activities should be } \\
\text { written in the learning plan }\end{array}$ \\
\hline
\end{tabular}

Based on some suggestions above validators, researchers revise the learning plan developed, so that learning plan can be used to assist in the process of learning activities of mathematics.

\section{Student's Worksheets}

Student's worksheets is designed based on the results of preliminary analysis conducted by researchers to: (1) analysis of learners. (2) analysis of learning problems, and (3) concept analysis. From the preliminary analysis result, it is designed student's worksheets based on Quantum Teaching on the material of class XI SMK semester 1. Students worksheets which has been designed validated by 5 experts consisting of 3 mathematicians, 1 language expert and 1 expert education technology. The didactic and content aspects were validated by 3 mathematicians, the language aspect validated by language experts and the aspect of graffitiality validated by educational technology experts. The average of student's worksheets validation results by experts can be seen in table 5 below.

TABLE 5. RESULTS OF VALIDATION OF STUDENT'S WORKSHEET BY EXPERTS

\begin{tabular}{|c|c|c|c|c|c|c|c|}
\hline \multirow{2}{*}{$\begin{array}{l}\text { Rated } \\
\text { aspect }\end{array}$} & \multicolumn{5}{|c|}{ Average Score from Validator } & \multirow{2}{*}{$\begin{array}{l}\text { Aver } \\
\text { age }\end{array}$} & \multirow[t]{2}{*}{ Criteria } \\
\hline & V1 & $V 2$ & V3 & V4 & V5 & & \\
\hline $\begin{array}{l}\text { Lingui } \\
\text { stic }\end{array}$ & - & - & - & 3,71 & - & 3,71 & $\begin{array}{c}\text { Very } \\
\text { Valid }\end{array}$ \\
\hline $\begin{array}{l}\text { Didact } \\
\text { ic }\end{array}$ & 3,14 & 4,00 & $\begin{array}{l}3,5 \\
7\end{array}$ & - & - & 3,57 & $\begin{array}{l}\text { Very } \\
\text { Valid }\end{array}$ \\
\hline $\begin{array}{l}\text { Conte } \\
\mathrm{nt}\end{array}$ & 3,20 & 4,00 & $\begin{array}{l}3,6 \\
7 \\
\end{array}$ & - & - & 3,63 & $\begin{array}{c}\text { Very } \\
\text { Valid }\end{array}$ \\
\hline $\begin{array}{l}\text { Graffi } \\
\text { ti }\end{array}$ & - & - & - & - & 3,86 & 3,86 & $\begin{array}{c}\text { Very } \\
\text { Valid }\end{array}$ \\
\hline \multicolumn{6}{|c|}{ Average } & 3,69 & $\begin{array}{l}\text { Very } \\
\text { Valid }\end{array}$ \\
\hline
\end{tabular}

Adjective : V1, V2 dan V3 : expert of Mathematic

V4 : expert of Indoensian Language

V5 : expert of education technology 
From table 5 we can see that all aspects assessed in student's worksheets are at very valid criteria. This means that student's worksheets has been developed feasible and can be used as one of the learning devices in the process of teaching and learning activities. Student's worksheets developed eligible for use because in the design process student's worksheets refers to the steps of making student's worksheets according to mone [8] and on matters contained in student's worksheets refer to prajitno's opinion [9].

Based on the average scoring score, all aspects of the assessment are at a very valid katerogi. Nevertheless, there are still some things in the student's worksheets that researchers need to improve in order for student's worksheets to be better developed. The suggestion of student's worksheets improvement from the validators can be seen in table 6 below

\section{TABLE 6. REVISED VALIDATION RESULTS OF STUDENT} WORKSHEET

\begin{tabular}{|l|l|}
\hline \multicolumn{1}{|c|}{ Before Revision } & \multicolumn{1}{|c|}{ After Revision } \\
\hline $\begin{array}{l}\text { Cover is less attractive and the } \\
\text { image on the cover is too small }\end{array}$ & $\begin{array}{l}\text { Fix the cover of student's } \\
\text { worksheets and display the } \\
\text { images that represent the contents } \\
\text { of student's worksheets }\end{array}$ \\
\hline $\begin{array}{l}\text { The title student's worksheets do } \\
\text { not use the word "activity 1, } \\
\text { activity 2, etc." }\end{array}$ & $\begin{array}{l}\text { Replacing "activity 1, activity 2, } \\
\text { etc." to student's worksheets 1, } \\
\text { student's worksheets 2, etc. " }\end{array}$ \\
\hline $\begin{array}{l}\text { Every problem on student's } \\
\text { worksheets has no number }\end{array}$ & $\begin{array}{l}\text { Numbering for each problem on } \\
\text { lkdp makes it easier to direct } \\
\text { learners in learning }\end{array}$ \\
\hline $\begin{array}{l}\text { There are still some sentences in } \\
\text { the student's worksheets that are } \\
\text { not yet complete }\end{array}$ & $\begin{array}{l}\text { Complete the sentence on student's } \\
\text { worksheets so as not to create } \\
\text { double meaning and learners more } \\
\text { easily understand the problem on } \\
\text { student's worksheets }\end{array}$ \\
\hline
\end{tabular}

Based on some of the above validator's suggestions, the researcher revised the student's worksheets developed for student's worksheets to be used to assist the learning process.

\section{CONCLUSION AND SUGGESTION}

Based on the results and discussion of the research found that learning devices developed by researchers have been valid The suggestions for the next researchers who develop learning devices to pay more attention to the accuracy of typing, sentences effective and in accordance with cognitive level of students, and refer to right development procedures of learning plan and students worksheets.

\section{REFERENCES}

[1] Abdurrahman. M, Anak Berkesulitan Belajar: Teori, Diagnosis, dan Remediasinya, Rineka Cipta, Jakarta, 2012.

[2] Cockroft, W. H, Mathematics Count, Commercial Colour Press, London, 1982.

[3] Widiyaningsih, E \& Pujiastuti, E, "Keefektifan Pembelajaran Model Quantum Teaching berbantu Cabri 3D Terhadap kemampuan Pemecahan Masalah", Jurnal Kreano. Jurusan Matematika FMIPA UNNES, Vol. 4, ISSN : 2086-2334, 2013.

[4] A'la, Miftahul, Quantum Teaching (buku Pintas dan Praktis), Jogjakarta: DIVA Press, 2010

[5] Plomp, T \& N. Nieveen, "Educational Design Research", Enshede: Netherlands Institute For Curriculum Development (SLO), 2013.
[6] Muliyardi, Strategi Pembelajaran Matematika, Padang: FMIPA UNP, 2002.

[7] Majid. Abdul, Implementasi Kurikulum 2013, Bandung: Interes Media, 2014.

[8] Depdiknas, Panduan Pengembangan Bahan Ajar,Jakarta: Direktorat Jendral Manajemen Pendidikan Dasar Dan Menengah, 2008.

[9] Megawati, "Pengembangan Perangkat Pembelajaran Matematika Berbasis Pendidikan Karakter Dengan Pendekatan Contextual Teaching And Learning Untuk Siswa Kelas X Sekolah Menengah Atas", Tesis Unpublished, Padang: Program Pascasarjana UNP, 2014. 